\title{
Henrik Wergeland: Selvmord
}

Skulde det virkelig for A Ivor være nødvendigt, at vise hvormeget Selvmordet, -- denne $\mathrm{H}$ andling, som strider saa mod en for den hele Skabning al mindelig $\mathrm{N}$ aturdrivt, den at vedligeholde sin Tilværelse, og som kun M ennesket kan tillade sig -- er en Tilsidesættelse af Pligt mod sig selv, mod $N$ aturens $O$ verherre, mod Guds Bud, mod Fædreneland, Slægt og Venner? G rundene mod Tilladeligheden af dette Foretagende, understøttede ved den enhver Skabning indprentede A fsky for Døden, kunne ikke andet end være overbevisen de for enhver kold Betragter og O verveier. M en den U lykkelige, som ingen Ende øiner paa sin Jammer, for hvem det sidste $\mathrm{G}$ limt af $\mathrm{H}$ aab er udsl ukt, og som overvæl des af mørke U dsigter, -- denne Ynkværdige kan vel ikke altid ventes tilbageholdt ved $G$ runde, hentede fra $\mathrm{H}$ andlingens $\mathrm{U}$ tilladelighed. D et nærværende 0 nde, naar alt $\mathrm{H}$ aab forsvinder, er desværre -- som kun altfor mange Exempler vise -- istand til at døve enhver anden Betragtning, enhver Følelse.

A t udvide $\mathrm{H}$ aabets $\mathrm{G}$ rændser maatte vel være det kraftigste $M$ iddel til at svække det $\mathrm{O}$ ndes Indtryk. Det er $\mathrm{H}$ aabet, som ligger til $\mathrm{G}$ rund for $M$ enneskets kraftfulde $\mathrm{H}$ andlinger, for dets $\mathrm{O}$ poffrelser. $\mathrm{H}$ aabet er Taalmodighedens $\mathrm{H}$ ovedbestanddeel. $\mathrm{U}$ den $\mathrm{H}$ aab er det moralske $\mathrm{M}$ enneske livløst som Liget; dets Vilje uden Selvstændighed, det er ganske Slave. M od M ismod i U lykker og mod Fortvivlelse, $M$ ismodets $F ø l$ gesvend, er da $\mathrm{H}$ aabet det eneste Virksomme, og det Eneste, som kan opholde Taalmodet og de synkende Sjelskræfter.

Til at styrke og fremkalde $\mathrm{H}$ aabet synes intet at være nærmere end Erfaringen om de menneskelige Tings 0 mvexlinger. -- "Fordi det er slemt nu, skulde det derfor ogsaa i Fremtiden blive saa?" har en af de $\mathrm{G}$ amle spurgt. Der er intet stadigt, intet stillestaaende under $\mathrm{M}$ aanen; den hele $\mathrm{N}$ atur er i bestandig Forandring, gaaen de frem og tilbage, og erstattende med retfærdig $\mathrm{H}$ aand til anden Tid det til een Tid efter Tingenes 0 rden nødven dige mindre $\mathrm{G}$ ode. Saaledes følges Vinteren af Vaaren; den klare og rolige Dag lader glemme Stormens Slud; den indstrømmende fri Lufts Bal som opliver de svage Livsaander, og udsl etter Erindringen om Sygel ejets Smerter.

Et Tilbagesyn over Tildragelserne, og EnhversErfaring om $\mathrm{H}$ ændelserne, som han har oplevet omkring sig, vil lære, at der er vel saa megen Rimelighed for, at den U heldiges Kaar maa kunne forbedres, forudsat at han ikke selv bestemt arbeider mod deres Forbedring, som for at den saakaldte Lykkelige vedbliver uafbrudt i Besiddelse af sin misundte Lykke. $\mathrm{H}$ vor mange Taarer har ikke Enhver, som har villet agte herpaa, seet aftørrede i Øjne, der ingen $U$ dvej saae! H vor kraftig er ikke Tiden til at lette Sorg, lindre Smerter, afhjæl pe Trang! $\mathrm{H}$ vor mange have ikke i $\mathrm{H}$ aabet om heldigere $D$ age fundet $\mathrm{K}$ raft til at kjæmpe mod det nærværende 0 nde og at arbeide sig frem til det bedre! O $\mathrm{g}$ da, hvilke behagelige Følelser er ikke en saadan forandret Tilstand forbunden med, fremfor den vedvarende Lykkes Kjedsomhed?

Kunde det da end nogensinde ansees undskyldeligt, at den U lykkelige søgte i Dødens A rme Enden paa sin Jammer, maatte det dog først være, naar der intet for ham meer her i Verden ellers kunde være at haabe, naar enhver anden $U$ dvej var ham for bestandig spærret. Det kunde al drig før betragtes som den sidste Tilflugt, som et mindre 0 nde. $M$ en naar indtræffer dette? og hvor er det M enneske, hvis Stilling er saadan, at den umuligen kan forbedres, at $\mathrm{N}$ aturens $\mathrm{K}$ raft og Tilfældene og Tingenes 0 rden og 0 mvexlinger ingen Indflydel se mere have eller kunne have paa hans Stillings Forandring? N aar da Døden vælges som den sidste Tilflugt, væl ges den altid for tidligen. $0 \mathrm{~g}$ hvorfor

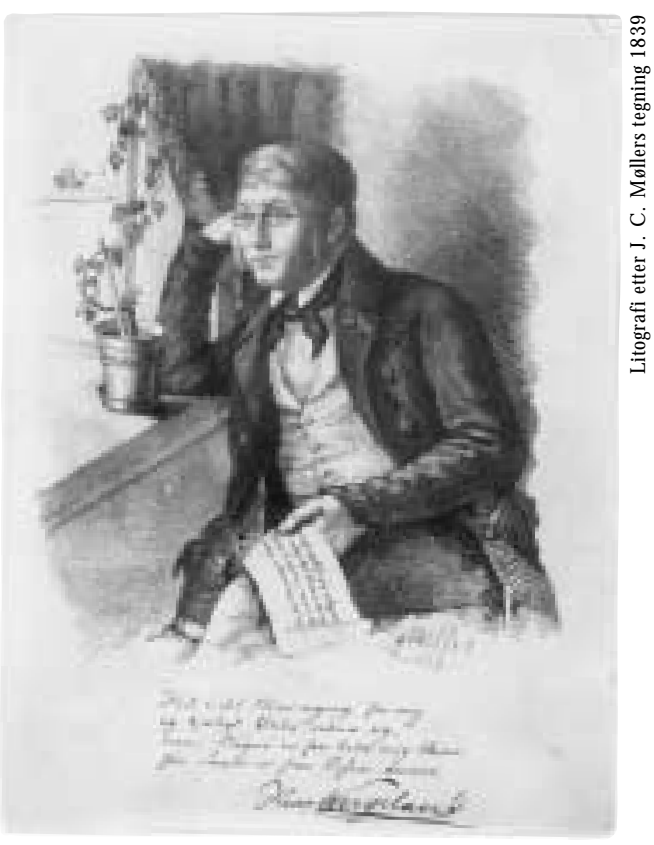

at overile sig? Dødens A rme staae jo altid aabne. Dette Tilflugtsted, forsaavidt G raven derfor kan ansees, er det ikke nødvendigt at passe $\emptyset$ jeblikket for at nytte. U dsættelse i H aab om Forbedring berøver ikke dertil A dgang. Derimod berøver 0 verilelsen $M$ ennesket $A$ dgang til Forandring i Vilkaar og i Sindsstemning, de glade og behagelige Følelser, som følge med Forandring, Leiligheden til at være fremdel es nyttig, at forøge Summen af det $\mathrm{G}$ ode, det efter sin Bestemmelse og i sin Vej har virket og kan virke og det $\mathrm{H}$ aab, ved $\mathrm{U}$ dgangen af Verden at see til bage over et længere vel anvendt eller rettet og ikke unyttigt Liv. -- Vi igjentage det: $0 \mathrm{~m}$ der end var intet andet, som maatte og burde tilbageholde M ennesket fra Selvmord, burde dog den Betragtning gjøre det, at det altid foretages for tidligen.

"Selvmord" er hentet fra Samlede skrifter. IV. A vhandlinger, O pplysningsskrifter 6. bind: $1839-1843$.

Denne teksten er basert på den digitale versjonen som ble skannet, O CR-lest, korrekturlest og SG M L-tagget av Dokumentasjonsprosjektet ved U niversitetet i O slo i 1991-1997, http://www. dokpro.uio.no /wergeland/ W IV 6/W IV 6027.html.

( Vi takker G ylden dal N orsk Forlag A S for utlån av bilder.) 